НАУКОВИЙ ВІСНИК

Sientific messenger of Lviv National University

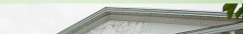

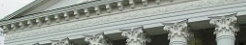

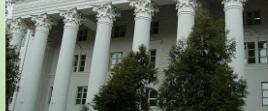

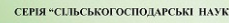

Том 22 № 93

2020
Науковий вісник Яьвівського національного університету ветеринарної медицини та біотехнологій імені С.3. Гжицького. Серія: Сільськогосподарські науки

Scientific Messenger of Lviv National University of Veterinary Medicine and Biotechnologies. Series: Agricultural sciences

UDC 575.113:577.21:636.05

\title{
Features of the genetic structure of the Simmental breed cattle
}

\author{
V. Y. Bodnaruk, L. I. Muzyka, Y. G. Kropyvka, P. V. Bodnar, A. J. Zhmur, T. V. Orikhivskyj \\ Stepan Gzhytskyi National University of Veterinary Medicine and Biotechnologies Lviv, Ukraine
}

Article info

Received 14.09.2020

Received in revised form 14.10 .2020

Accepted 15.10.2020

Stepan Gzhytskyi National University of Veterinary Medicine and Biotechnologies Lviv, Pekarska Str., 50, Lviv, 79010, Ukraine.

Tel.: +38-032-239-26-82 E-mail: bodnaruk.vol@gmail.com
Bodnaruk, V. Y., Muzyka, L. I., Kropyvka, Y. G., Bodnar, P. V., Zhmur, A. J., \& Orikhivskyj, T. V. (2020). Features of the genetic structure of the Simmental breed cattle. Scientific Messenger of Lviv National University of Veterinary Medicine and Biotechnologies. Series: Agricultural sciences, 22(93), 137-141. doi: 10.32718/nvlvet-a9323

Breeds of farm animals are characterized by the presence of their genetic structure, in particular, the distribution of allelic and genotypic frequencies by individual genetic and biochemical systems. The purpose of our search was to study the genetic frequencies of polymorphic loci of transferrin (TF), amylase (AM), ceruloplasmin (CR), hemoglobin (HB) and purine nucleoside phosphorylase (PN) in Simmental cattle and related breeds (Gray Ukrainian and Charolais), as well as to determine the degree of similarity between the expected loci and actual genotypes. As a result of research it was established that the genetic structure of the studied polymorphic loci of the Simmental breed was closer in animals of the Gray Ukrainian breed. In particular, at the locus of transferrin in individuals of the Gray Ukrainian breed there are alleles $T F A, T F$ $D 1, T F D 2$ and TF E, whose genetic frequency was in the range of 0.051-0.603. The frequency of the Tf $A$ allele in all studied breeds of cattle had a slight intergroup fluctuations (0.235-0.244), indicating their genetic similarity to this allele. At the locus of transferrin allele Tf DI of the breed Ukrainian and Charolais were characterized by a lower frequency, however, according to the Tf D2 allele (frequency 0.603 in both breeds), they outperformed the Simmental breed by $11.7 \%$. The amylase locus in the studied breeds occurs with the alleles $A M B$ and $A M C$, and with the allele $A M A-i$ s absent. The frequency of the $A M B$ allele was highest in animals of the Gray Ukrainian breed, and in the AM C allele in the Charolais breed. It should be noted the high frequency of the AM B allele (0.910) in the Gray Ukrainian breed, which is due to the large number of BB homozygotes. Among the ceruloplasmin locus, the CP A allele had the highest frequency, and the $C P B$ allele had a slightly lower frequency. In the hemoglobin locus, the frequency of $H B A$ allele expression was the highest compared to other polymorphic systems and was in the range of 0.905-1.000. As for the HB B allele, on the contrary, the frequency of its appearance was much lower: in Simmental animals it was 0.095, in the Charolais breed it was 0.059, and in the Gray Ukrainian breed this allele was not observed. Among the alleles of purine nucleoside phosphoryls, the PN L allele was noted with a high frequency (0.697-0.846). The study of genotypes of genetic and biochemical systems of Simmental breed by loci $T F, A M, S R, H B$ and $P N$ shows that the locus $T F$, which is represented by the largest number of genotypes (10), was marked by a high degree of similarity between expected and actual genotypes with a significant difference (exception - genotype TF EE). The largest number of animals at this locus had the genotypes TF AD2, TF D1 D2 and TF D2 D2 (8 heads in each group), and the smallest - with genotypes TF $A A, T F D 1 D 1, T F D 1 E$ and TF D2 E (1-2 heads each). With the expected genotypes TF AF and TF EE, their real number was not detected, which indicates high heterozygosity. Amylase polymorphism is appeqred only by alleles AM B and AM C. Homozygous for allele B recorded a slightly larger number - in 23 individuals, while homozygous for allele $C$-only in 3 individuals, which coincides with the expected data in accordance with 21.690 and 1.690. The ceruloplasmin locus is marked by a slightly higher frequency of allele $A$, due to homo- (CP $A A)$ and heterozygotes $(C P A B)$, which appeared in 15 animals in both groups. Hemoglobin in the Simmental breed, as in most breeds of cattle, is represented mainly by allele $A$, and homozygotes of the BB allele are absent. Allele $B$ is appeared in small quantities in a heterozygous state - in 4 individuals. The PN locus is appeared by two alleles ( $L$ and $H$ ), and there are no heterozygotes on the electrophoresis foregrams. There was a high frequency of the L allele of the PN locus, which is characteristic of breeds of the dairy direction of productivity. The PN H allele, which is characterized by high activity, is somewhat less common in Simmentals (only in 6 individuals). Thus, the study of genetic frequencies of the Simmental breed is necessary for the identification and early determination of the level of productivity of animals. Genetic frequencies of polymorphic loci are necessary for selection work with the breed, and can also be used in the breeding process to accelerate the rate of the breeding process. Searches 
of the genetic structure of the complex of genetic and biochemical systems are necessary for the research and preservation of the gene fund of local and endangered breeds of cattle.

Key words: Simmental breed, genetic structure, genetic markers, genetically determined sign, hemoglobin, transferrin, ceruloplasmin, purine nucleoside phosphorylase.

\title{
Особливості генетичної структури симентальської породи великої рогатої худоби
}

\author{
В. Є. Боднарук, Л. І. Музика, Ю. Г. Кропивка, П. В. Боднар, А. Й. Жмур, Т. В. Оріхівський
}

Львівський національний університет ветеринарної медицини та біотехнологій імені С. 3. Гжицького, м. Львів, Україна

Породи сільськогосподарських тварин характеризується наявністю своєї генетичної структури, зокрема розподілом алельних і генотипових частот за окремими генетико-біохімічними системами. Метою наших досліджень було вивчити генетичні частоти поліморфних локусів трансферину (TF), амілази (АМ), иерулоплазміну (СР), гемоглобіну (НВ) та пуриннуклеозидфосфорилази (PN) у тварин симентальської породи великої рогатої худоби та близьких до неї порід (сірої української та шароле), а також визначити за названими локусами ступінь схожості між очікуваними та реальними генотипами. В результаті досліджень встановлено, шо генетична структура досліджуваних поліморфних локусів симентальської породи більш близькою виявилася у тварин сірої украӥнської породи. Зокрема, за локусом трансферину у особин сірої української породи зустрічаються алелі ТF А, ТF Д1, ТF Д2 та TF Е, генетична частота яких була в межах 0,051-0,603. Частота алелю Tf А у всіх досліджуваних порід великої рогатої худоби мала незначне міжгрупове коливання (0,235-0,244), щчо вказує на їх генетичну подібність за ичи алелем. За локусом трансферину алелю Tf D1 породи сіра українська та шароле характеризувалися нижчою частотою, проте за алелем Tf D2 (частота 0,603 в обох порід) вони переважали симентальську породу - на 11,7 \%. Локус амілази у досліджуваних породах зустрічається з алелями $A M B$ i $A M C$, а з алелем AM A - відсутній. Частота алелю АМ В найвищою була у тварин сірої украӥнської породи, а за алелем АM C - у шаролезької породи. Необхідно відмітити високу частоту алелю АМ B (0,910) у сірої української породи, шзо зумовлено великою кількістю гомозигот ВВ. Серед локусу иерулоплазміну вишу частоту мав алель СР А, дешо нижчу - алель СР В. У локусі гемоглобіну частота проявлення алелю НВ А була найвищою порівняно з іншими поліморфними системами $і$ знаходилася в межах 0,905-1,000. Щодо алелю НВ В, то навпаки, частота його проявлення була значно нижчою: у тварин симентальської породи вона становила 0,095, породи шароле - 0,059, а у сірої украӥнської породи даний алель не спостерігався. Серед алелей пуриннуклеозидфосфорили високою частотою $(0,697-0,846)$ відзначався алель PN L. Вивчення генотипів генетико-біохімічних систем симентальської породи за локусами TF, АМ, СP, НB і PN свідчить, щзо локус TF, який представлений найбільиою кількістю генотипів (10), відзначався високим ступенем схожості між очікуваними та реальними генотипами за достовірної різниці (виняток - генотип TF EE). Найбільша кількість тварин за цим локусом мали генотипи TF AD2, TF D1 D2 i TF D2 D2 (по 8 голів у кожній групі), а найменша - з генотипами TF AA, TF D1 D1, TF D1 E i TF D2 E (по 1-2 голови). За очікуваних генотипів TF AF та TF EE ̈̈х реальна кількість не виявлена, щуо вказує на високу гетерозиготність. Поліморфізм амілази проявляється тільки за алелями АМ В $і$ АМ С. Гомозизот за алелем В зафіксовано дещо більшу кількість - у 23 особинах, коли гомозигот за алелем $C$ - лише у 3 особинах, що співпадає з очікуваними даними у відповідності 21,690 і 1,690. Локус иеерулоплазміну відзначається дещзо вищою частотою алелю A, за рахунок гомо- (CP АA) та гетерозигот (CP АB), які проявилися у 15 тварин в обох групах. Гемоглобін у симентальської породи, так як і в більшості порід великої рогатої худоби, представлений в основному алелем А, а гомозигот алелю ВВ взагалі відсутні. Алель В в незначній кількості проявлясться в гетерозиготному стані - у 4 особин. Локус PN проявляється двома алелями (L $і$ Н), при чому на електрофорезних фореграмах відсутні гетерозиготи. Спостерігалася висока частота алелю L локусу РN, щяо характерно для порід молочного напрямку продуктивності. Алель РN Н, для якого властива висока активність, проявляється у сименталів дещо рідше (лише у 6 особин). Таким чином, вивчення генних частот симентальської породи необхідне для ідентифікацї та раннього визначення рівня продуктивності тварин. Генетичні частоти поліморфних локусів необхідні для селекиійної роботи з породою, а також можуть бути використані в породотворчому прочесі для прискорення темпів селекиійного проиесу. Дослідження генетичної структури за комплексом генетико-біохімічних систем необхідні для вивчення $і$ збереження генофонду локальних та зникаючих порід великої рогатої худоби.

Ключові слова: симентальська порода, генетична структура, генетичні маркери, генетично детермінована ознака, гемоглобін, трансферин, иерулоплазмін, пуриннуклеозидфосфорилаза.

\section{Вступ}

Теоретичні та методичні засади створення і консолідації нових порід сільськогосподарських тварин грунтуються на використанні загальногенетичних закономірностей, зокрема шляхом спрямованого добору бажаних генотипів та їх відтворення. Добір i підбір, що забезпечує одержання бажаних генотипів реалізується через впровадження досягнень сучасної генетики, творче поєднання різних напрямів генетичних та біологічних досліджень. Насичення генофонду конкретним алелем відбувається у двох випадках при інтенсивному використанні плідника який $є$ носієм даного алелю, та при переважному успадкуванні такого алелю. Одним 3 ефективних методологічних підходів до використання імуногенетичних маркерів може бути аналіз розподілу альтернативних алелей, що створює передумови для оцінки селективної цінності генетичного матеріалу, який маркірує відповідний алель, а також спрямовані на запобігання звуження генофонду популяцій (Podoba et al., 2010; Podoba et al., 2012; Rossokha et al., 2019).

Порода сільськогосподарських тварин - це складна та динамічна біологічна система, яка відображає специфіку, напрямок та інтенсивність дії різних форм добору, дрейфу генів. Вона характеризується наявністю своєї генетичної структури, зокрема розподілом алельних і генотипових частот за окремими генетико- 
біохімічними системами (Winder et al., 1990; Chumel, 2004; Bodnaruk et al., 2014; Shcherbatyj et al., 2015; Shcherbatyj et al., 2016; Bodnaruk et al., 2016; Bodnaruk et al., 2017a; Bodnaruk et al., 2017b).

На думку Й. 3. Сірацького (Sirackyj et al., 1998), підвищенню ефективності використання породних ресурсів сприяють два основні моменти: 1) знання вимог сучасних технологічних схем виробництва в тваринництві; 2) знання відмінностей породних особливостей, щоб на основі їх поєднання визначити найвдаліші варіанти схрещування. Таким чином, першочергового значення набуває вивчення генетичних особливостей порід, які розводяться.

Застосування молекулярно-генетичних маркерів $є$ невід'ємним елементом системи збереження в Україні генофонду тварин, шляхом визначення найбільш цінних генотипів та створює реальні передумови для їх спрямованого використання в програмах із охорони біорізноманіття у популяціях великої рогатої худоби України (Kopylova et al., 2013).

3 огляду на зазначене, метою наших досліджень було вивчити генетичні частоти поліморфних локусів трансферину, амілази, церулоплазміну, гемоглобіну та пуриннуклеозидфосфорилази у тварин симентальської породи та близьких до неї порід (сірої української та шароле), а також визначити за названими локусами ступінь схожості між очікуваними та реальними генотипами.

\section{Таблиця 1}

Генетичні частоти поліморфних локусів симентальської породи та близьких до неї порід

\begin{tabular}{cccc}
\hline \multirow{2}{*}{ Локуси } & \multicolumn{3}{c}{ Порода } \\
\cline { 2 - 4 } TF (n) & симентальська & сіра українська & шароле \\
A & 35 & 39 & 0,235 \\
D1 & 0,243 & 0,244 & 0,162 \\
D2 & 0,229 & 0,051 & 0,603 \\
E & 0,486 & 0,603 & 0,000 \\
AM (n) & 0,043 & 0,103 & 34 \\
A & 36 & 39 & 0,000 \\
B & 0,000 & 0,000 & 0,676 \\
C & 0,778 & 0,910 & 0,324 \\
CP (n) & 0,222 & 0,090 & 34 \\
A & 35 & 39 & 0,662 \\
B & 0,643 & 0,731 & 0,338 \\
HB (n) & 0,357 & 0,269 & 34 \\
A & 21 & 39 & 0,941 \\
B & 0,905 & 1,000 & 0,059 \\
L (n) & 0,095 & 0,000 & 33 \\
H & 25 & 39 & 0,697 \\
\hline
\end{tabular}

Слід зазначити, що локус трансферину у великої рогатої худоби відзначається найбільшою кількістю алелей. Разом з тим, у породи шароле локус трансферину алелю Tf Е не виявлено. Частота алелю Tf A у всіх досліджуваних порід великої рогатої худоби мала незначне міжгрупове коливання $(0,235-0,244)$, що вказує на їх генетичну подібність за цим алелем. За локусом трансферину алелю Tf D1 породи сіра українська та шароле характеризувалися нижчою частотою, проте за алелем Tf D2 (частота 0,603 в обох

\section{Матеріал і методи досліджень}

Генетичну структуру оцінювали за генетично детермінованим поліморфізмом груп генетикобіохімічних систем. Досліди проводились на еритроцитах і плазмі крові. Кров у тварин брали $з$ яремної вени в пробірку з гепарином. Поліморфізм білків та ферментів оцінювали, застосовуючи метод електрофоретичного розділення білків у 13 \% крохмальному гелі в горизонтальних мікро та звичайних камерах 3 подальшим гістохімічним фарбуванням (Harris \& Hopkinson, 1976).

\section{Результати та їх обговорення}

Результати наших досліджень показали, що генетична структура симентальської породи за поліморфними локусами трансферину (TF), амілази (AM), церулоплазміну (СР), гемоглобіну (НВ) та пуриннуклеозидфосфорилази (PN) більш близькою до симентальської породи виявилася сіра українська порода великої рогатої худоби (табл. 1). Зокрема, у тварин сірої української породи серед локусу трансферину зустрічаються алелі TF А, TF Д1, TF Д2 та TF Е, генетична частота яких була в межах 0,051-0,603. порід) вони переважали симентальську породу - на $11,7 \%$.

Локус амілази у досліджуваних породах зустрічається 3 алелями АМ В і АM C, а 3 алелем АM А відсутній. Частота алелю АМ В найвищою була у тварин сірої української породи, а за алелем АМ C - у шаролезької породи. Необхідно відмітити високу частоту алелю АМ В у сірої української породи, яка становила 0,910. Така висока частота цього алелю зумовлена великою кількістю гомозигот ВВ. 
Серед локусу церулоплазміну вищу частоту мав алель СР А - від 0,643 (у тварин симентальської породи) до 0,731 (у тварин сірої української породи). Дещо нижча частота спостерігалася за алелем СР В: у тварин симентальської породи та шароле вона була вищою, порівняно із сірою українською породою. За цим алелем різниця між вказаними породами складала в межах 1,9-8,8 \% на користь симентальської.

У локусі гемоглобіну частота проявлення алелю НВ А була найвищою порівняно $з$ іншими поліморфними системами і знаходилася в межах 0,905-1,000. Щодо алелю НВ В, то навпаки, частота його проявлення була значно нижчою: у тварин симентальської породи вона становила 0,095, породи шароле - 0,059, a у сірої української породи даний алель не спостерігався.

Пуриннуклеозидфосфорилаза (PN) - фермент, локус якого представлений двома аллелями: PN L та PN Н. Серед цих алелей високою частотою відзначався алель PN L: у досліджуваних порід частота цього алелю складала в межах 0,697-0,846. За цим алелем проміжне місце займала симентальська порода. Що стосується алелю PN H (характерний для тварин м'ясного напрямку продуктивності), то частота його проявлення, порівняно із алелем PN L, була нижчою та становила від 0,154 до 0,303.

Нами проведено також вивчення генотипів генетико-біохімічних систем симентальської породи за локусами трансферину (TF), амілази (AM), церулоплазміну (СР), гемоглобіну (НВ) і пуриннуклеозидфосфорилази (PN), результати яких наведені у таблиці 2. Так, локус трансферину, який представлений найбільшою кількістю генотипів (10), відзначався високим ступенем схожості між очікуваними та реальними генотипами за достовірної різниці (виняток - генотип TF EЕ). У симентальської породи найбільша кількість тварин за локусом трансферину мали генотипи ТF AD2, TF D1 D2 i TF D2 D2 - по 8 голів у кожній групі, а найменша - 3 генотипами TF AA, TF D1 D1, TF D1 E i TF D2 E - по 1-2 голови. За очікуваних генотипів TF AF та TF EE їх реальна кількість не виявлена, що вказує на високу гетерозиготність.

Таблиця 2

Генотипи генетико-біохімічних локусів симентальської породи: реальні та очікувані

\begin{tabular}{|c|c|c|c|c|}
\hline Локуси & Генотипи & Реальні & Очікувані & Достовірність \\
\hline \multirow{10}{*}{$\mathrm{TF}$} & $\mathrm{AA}$ & 2 & 1,971 & \\
\hline & AD1 & 5 & 3,942 & \\
\hline & AD2 & 8 & 8,377 & \\
\hline & $\mathrm{AF}$ & 0 & 0,739 & \\
\hline & D1 D1 & 1 & 1,739 & \\
\hline & D1 D2 & 8 & 7,884 & \\
\hline & D1 E & 1 & 0,696 & \\
\hline & D2 D2 & 8 & 8,130 & \\
\hline & D2 E & 2 & 1,478 & \\
\hline & $\mathrm{EE}$ & 0 & 0,043 & 0,944 \\
\hline \multirow{3}{*}{$\mathrm{AM}$} & BB & 23 & 21,690 & \\
\hline & $\mathrm{BC}$ & 10 & 12,620 & \\
\hline & $\mathrm{CC}$ & 3 & 1,690 & 0,201 \\
\hline \multirow{3}{*}{$\mathrm{CP}$} & AA & 15 & 14,348 & \\
\hline & $\mathrm{AB}$ & 15 & 16,304 & \\
\hline & $\mathrm{BB}$ & 5 & 4,348 & 0,630 \\
\hline \multirow{3}{*}{ HB } & AA & 17 & 17,146 & \\
\hline & $\mathrm{AB}$ & 4 & 3,707 & \\
\hline & $\mathrm{BB}$ & 0 & 0,146 & 0,679 \\
\hline \multirow{3}{*}{$\mathrm{PH}$} & & 19 & 14,347 & \\
\hline & $\mathrm{L}$ & 0 & 9,306 & \\
\hline & $\mathrm{H}$ & 6 & 1,347 & \\
\hline
\end{tabular}

Поліморфізм амілази проявляється тільки за алелями АМ В і АМ С. Гомозизот за алелем В зафіксовано дещо більшу кількість - у 23 особинах, коли гомозигот за алелем С - лише у 3 особинах, що співпадає 3 очікуваними даними у відповідності 21,690 і 1,690.

Локус церулоплазміну відзначається дещо вищою частотою алелю А, за рахунок гомо- (СР АA) та гетерозигот (CР $\mathrm{AB})$, які проявилися у 15 тварин в обох групах.

Гемоглобін у симентальської породи, так як і в більшості порід великої рогатої худоби, представлений в основному алелем А, а гомозигот алелю ВВ взагалі відсутні. Алель В в незначній кількості проявляється в гетерозиготному стані - у 4 особин.
Локус пуриннуклеозидфосфорилаза (PN) проявляється двома алелями (L i H), при чому на електрофорезних фореграмах відсутні гетерозиготи. Висока частота алелю L (19) спостерігалася у симентальської породи, що характерно для порід молочного напрямку продуктивності. Алель РN Н, для якого властива висока активність, проявляється у сименталів дещо рідше (лише у 6 особин).

\section{Висновки}

1. Вивчення генних частот симентальської породи необхідне для ідентифікації тварин даної породи. Маркування спадкового матеріалу дасть можливість 
раннього визначення рівня продуктивності тварин даної породи.

2. Генетичні частоти поліморфних локусів необхідні для селекційної роботи 3 породою, а також можуть бути використані в породотворчому процесі для прискорення темпів селекційного процесу.

3. Дослідження генетичної структури за комплексом генетико-біохімічних систем необхідні для вивчення і збереження генофонду локальних та зникаючих порід великої рогатої худоби. Ці дослідження повинні розглядатися у відповідному комплексі 3 господарськи корисними ознаками.

Перспективи подальших досліджень. У подальшому буде досліджено генетичні частоти поліморфних локусів окремих порід великої рогатої худоби, яких розводять в західному регіоні України.

\section{References}

Bodnaruk, V., Shchebatyj, Z., Muzyka, L., Zhmur, A., \& Orikhivskyj, T. (2017a). Genofond of some breed of cattle. Scientific Messenger LNUVMBT named after S. Z. Gzhytskyj, 19 (74), 131-134. doi: $10.15421 /$ nvlvet7429.

Bodnaruk, V. Y., Kropyvka, Y. G., Muzyka, L. I., \& Zhmur, A. J. (2014). Osoblyvosti genetychnoi' struktury polis'koi' m'jasnoi' porody velykoi' rogatoi' hudoby (Genetic structure features polessie beef breed cattle). Scientific Messenger LNUVMB, 16, 3(60), 3, 21-25. URL: http://nbuv.gov.ua/UJRN/nvlnu_2014_16_3\%283\%29 6 (in Ukrainian).

Bodnaruk, V. Y., Muzyka, L. I., Bodnar, P. V., Zhmur, A. J., \& Orihivsjkyj, T. V. (2017b). New possibilities of effective breeding in cattle based on the study of the genome. Scientific Messenger LNUVMB, 19(79), 32 37. doi: $10.15421 /$ nvlvet7907.

Bodnaruk, V. Y., Muzyka, L. I., Zhmur, A.J ., \& Orikhivskyy, T. V. (2016). Comparative analysis of genetic and parental hybrids. Scientific Messenger LNUVMBT named after S. Z. Gzhytskyj, 18, 2(67), 21-24. doi: 10.15421/nvlvet6705.

Chumel, R. I. (2004). Genetyko-biohimichni ta produktyvni osoblyvosti hudoby pivnichno-shidnogo regionu Ukrai'ny. Avtoref. dys... kand. s.-g. nauk: 06.02.01 - rozvedennja ta selekcija tvaryn. Instytut rozvedennja i genetyky tvaryn. s. Chubyns'ke Kyi'vs'koi' oblasti. 23 (in Ukrainian).

Harris, H., \& Hopkinson, D. A. (1976). Handbook of enzyme electrophoresis in human genetics. Amsterdam: North-Holland Publ. Comp.

Kopylova, K. V., Shelev, A. V., Berezovskiy, O. V., Kopylov, K. V., \& Rossokha, V. I. (2013). Genetychna struktura riznyh porid velykoi' rogatoi' hudoby za molekuljarno-genetychnymy markeramy (Created by molecular and genetsc markers genetic structure of bulls from different breeds of cattle). Naukovo-tehnichnyj bjuleten' Instytutu tvarynnyctva NAAN, 110. 76-83. URL: http://nbuv.gov.ua/UJRN/Ntb_2013_110_14 (in Ukrainian).

Podoba, B. Y., Birukova, O. D., \& Kuhtina, K. V. (2012). Imunogenetychna ocinka specyfiky porid u systemi genetychnogo monitoryngu bioriznomanittja. Visnyk agrarnoi' nauky, 12, 43-47. URL: http://nbuv.gov.ua/ UJRN/vaan_2012_12_12 (in Ukrainian).

Podoba, B. Y., Kuhtina, K. V., \& Basovskyj, D. M. (2010). Metodologichni zasady i tendencii' vykorystannja imunogenetychnyh metodiv $\mathrm{u}$ pleminnomu tvarynnyctvi Ukrai'ny. Rozvedennja i genetyka tvaryn, 44, 153-156 (in Ukrainian).

Rossokha, V. I., Drobyazko, O. V., \& Boyko, O. A. (2019). Dynamyka zmin genetychnoi' struktury populjacii' velykoi' rogatoi' hudoby symental's'koi' porody za imunogenetychnymy kryterijamy (Dynamics of changes in the genetic structure of the Simmental breed by the immunogenetic criteria). Naukovo-tehnichnyj bjuleten' Instytutu tvarynnyctva NAAN, 122, 155-162. doi: 10.32900/2312-84022019-122-155-162 (in Ukrainian).

Shcherbatyj, Z. Y., Bodnaruk, V. Y., Bodnar, P. V., Muzyka, L. I., \& Zhmur, A. J. (2015). Porivnjal'nyj analiz blyz'korodynnyh vydiv velykoi' rogatoi' hudoby (The comparative analysis of species closely related cattle). Scientific Messenger LNUVMB, 17(1), 293299. URL: https://nvlvet.com.ua/index.php/ agriculture/article/view/3593 (in Ukrainian).

Shcherbatyj, Z. Y., Kozenko, O. V., Bodnaruk, V. Y., Muzyka, L. I., Zhmur, A. J., \& Orikhivskyy, T. V. (2016). Ukrainian gray breed of cattle. Scientific Messenger LNUVMB, 18, 1(65), 173-177. URL: https://nvlvet.com.ua/index.php/agriculture/article/vie w/3523/3491 (in Ukrainian).

Sirackyj, J. Z., Merkushyn, V. V., Kostenko, O. I., Podoba, B. Y., Bojko, V. P., Shapirko. V. V., \& Lyhobabina, V. M. (1998). Genofond jak systema, shho zabezpechuje optymal'nyj stan populjacii' (porody, vydu) tvaryn. Rozvedennja i genetyka tvaryn, 29, 17-24. URL: http://nbuv.gov.ua/jpdf/rgt_1998_29_5.pdf (in Ukrainian).

Winder, J. A., Brinks, J. S., Bourdon, R. M. \& Golden, B. L. (1990). Genetic analysis of absolute growth measurements, relative growth rate and restricted selection indices in red Angus cattle. J. Anim Sci. Feb, 68 (2), 330-336. doi: 10.2527/1990.682330x. 